\title{
One-Dimensional Simulation of Stratification and Dissolved Oxygen in McCook Reservoir, Illinois
}

Water-Resources Investigations Report 00-4258

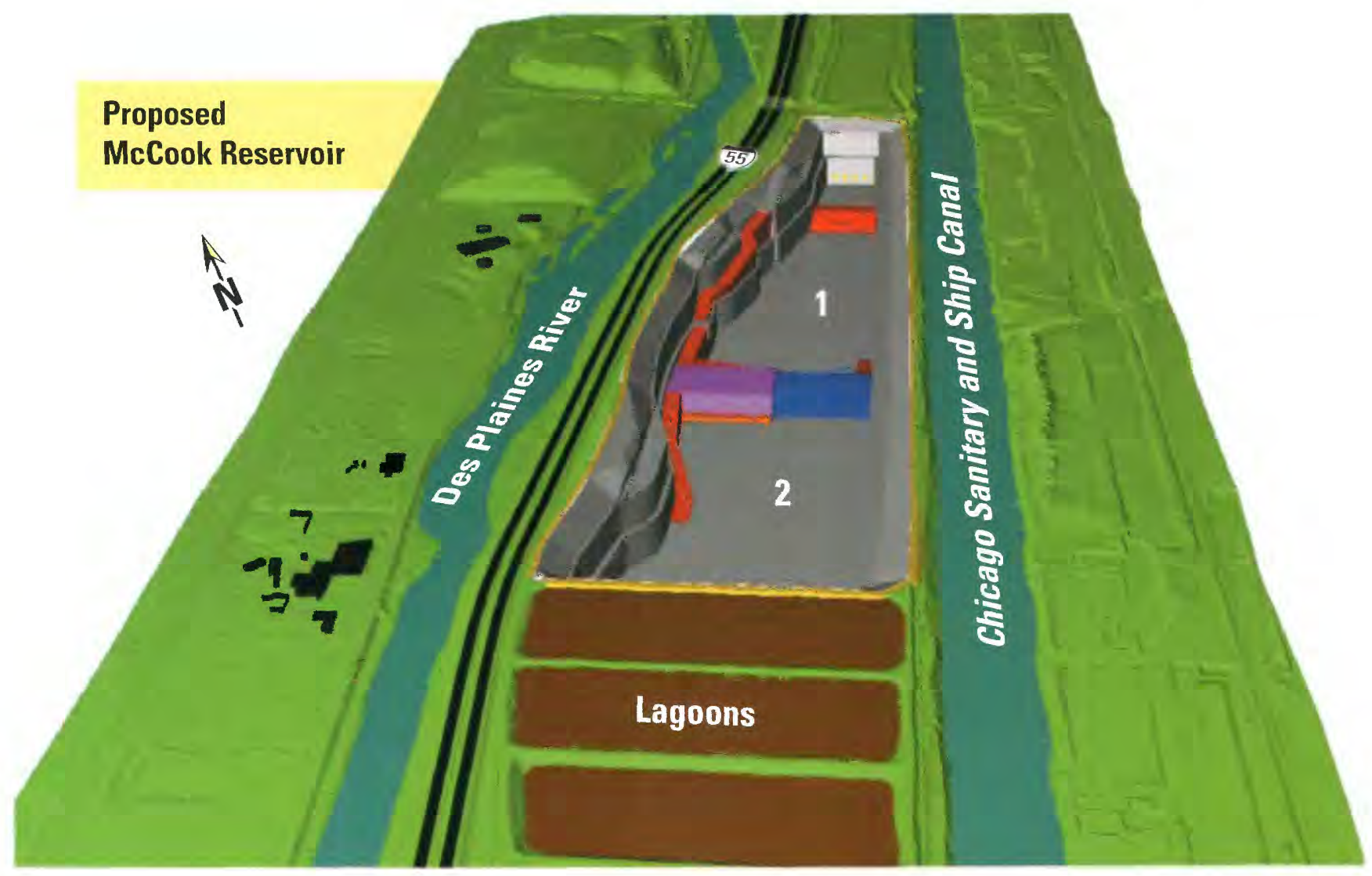

Prepared in cooperation with the U.S. Army Corps of Engineers

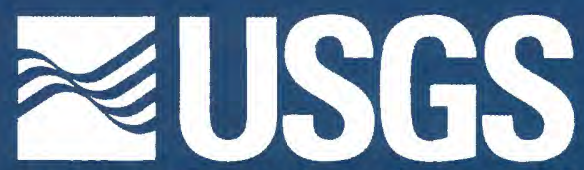





\section{One-Dimensional Simulation of Stratification and Dissolved Oxygen in McCook Reservoir, Illinois}

By Dale M. Robertson

U.S. GEOLOGICAL SURVEY

Water-Resources Investigations Report 00-4258

Prepared in cooperation with the U.S. Army Corps of Engineers 


\title{
U.S. DEPARTMENT OF THE INTERIOR BRUCE BABBITT, Secretary
}

\author{
U.S. GEOLOGICAL SURVEY \\ Charles G. Groat, Director
}

Any use of trade, product, or firm names is for descriptive purposes only and does not imply endorsement by the U.S. Government.

For additional information write to:

District Chief

U.S. Geological Survey

8505 Research Way

Middleton, WI 53562-3586
Copies of this report can be purchased from:

U.S. Geological Survey

Branch of Information Services

Box 25286

Denver, CO 80225-0286 


\section{CONTENTS}

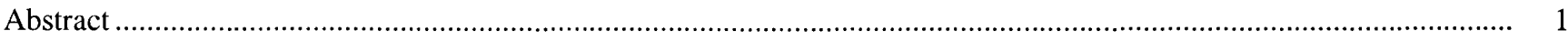

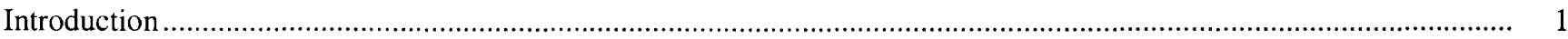

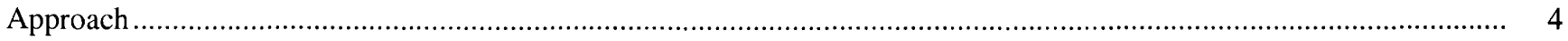

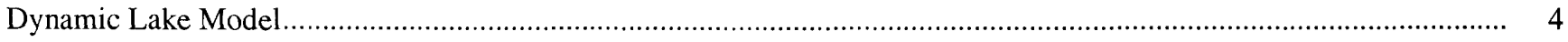

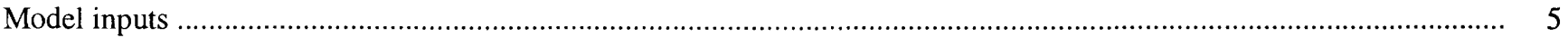

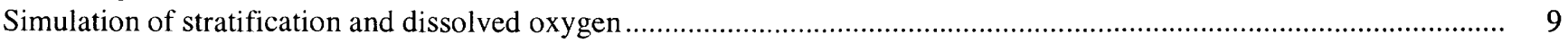

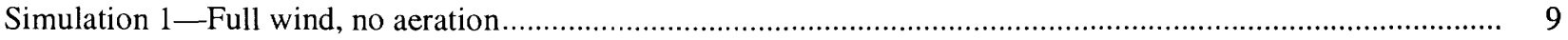

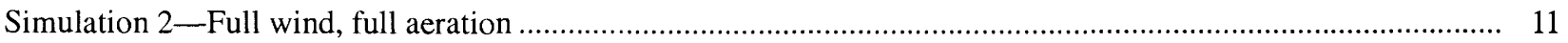

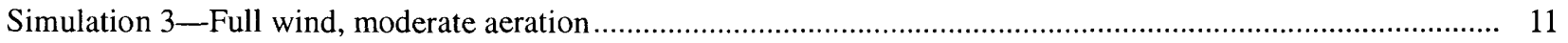

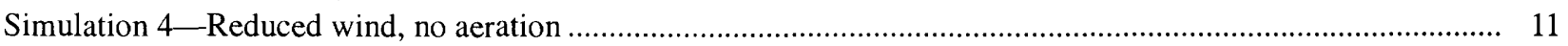

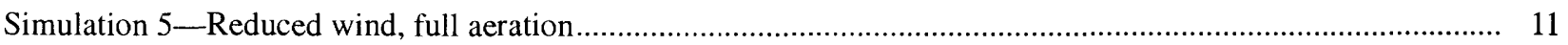

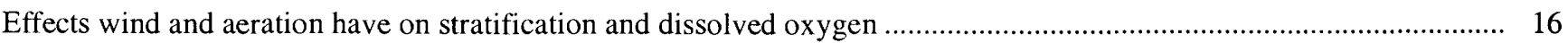

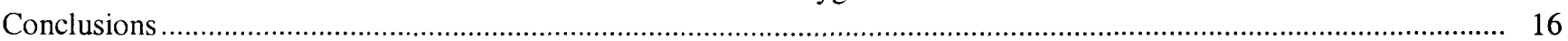

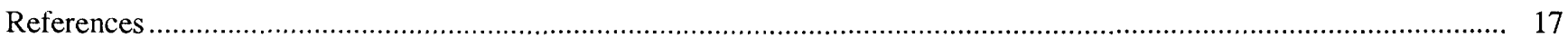

\section{FIGURES}

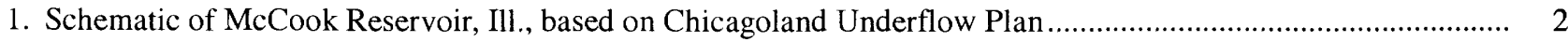

2-8. Graphs showing:

2. Daily average meterological data from St. Charles, Ill, from July 13, 1997 to August 10, 1997

3. Total daily inflow to and outflow from McCook Reservoir, Ill., during the 1-in-100-year event ..................... 9

4. Water temperature distribution in McCook Reservoir, Ill., simulated by DLM (full wind) ..............................10

5. Dissolved oxygen distribution in McCook Reservoir, Ill., simulated by DLM (full wind) ............................ 12

6. Temperature and dissolved oxygen distributions in McCook Reservoir, Ill., simulated by DLM (full wind, moderate aeration)

7. Water temperature distribution in McCook Reservoir, Ill., simulated by DLM (reduced wind) ....................... 14

8. Dissolved oxygen distribution in McCook Reservoir, Ill., simulated by DLM (reduced wind) ...................... 15

\section{TABLE}

1. Morphometry of McCook Reservoir, Ill 


\section{CONVERSION FACTORS AND ABBREVIATIONS}

\begin{tabular}{|c|c|c|}
\hline Multiply & By & To Obtain \\
\hline \multicolumn{3}{|c|}{ Length } \\
\hline $\begin{array}{r}\text { kilometer }(\mathrm{km}) \\
\text { meter }(\mathrm{m}) \\
\text { meter }(\mathrm{m})\end{array}$ & $\begin{array}{l}0.6214 \\
1.094 \\
3.281\end{array}$ & $\begin{array}{l}\text { mile } \\
\text { yard } \\
\text { foot }\end{array}$ \\
\hline \multicolumn{3}{|c|}{ Area } \\
\hline square meter $\left(\mathrm{m}^{2}\right)$ & 0.0002471 & acre \\
\hline \multicolumn{3}{|c|}{ Volume } \\
\hline $\begin{array}{l}\text { cubic meter }\left(\mathrm{m}^{3}\right) \\
\text { cubic meter }\left(\mathrm{m}^{3}\right) \\
\text { cubic meter }\left(\mathrm{m}^{3}\right)\end{array}$ & $\begin{array}{l}35.31 \\
1.308 \\
0.0008107\end{array}$ & $\begin{array}{l}\text { cubic foot } \\
\text { cubic yard } \\
\text { acre-foot }\end{array}$ \\
\hline \multicolumn{3}{|c|}{ Flow rate } \\
\hline $\begin{array}{r}\text { cubic meter per second }\left(\mathrm{m}^{3} / \mathrm{s}\right) \\
\text { cubic meter per day }\left(\mathrm{m}^{3} / \mathrm{d}\right)\end{array}$ & $\begin{array}{l}35.31 \\
35.31\end{array}$ & $\begin{array}{l}\text { cubic foot per second } \\
\text { cubic foot per day }\end{array}$ \\
\hline \multicolumn{3}{|c|}{ Energy } \\
\hline kilojoules (kj) & 0.00028 & kilowatt hour \\
\hline
\end{tabular}

Temperature, in degrees Celsius $\left({ }^{\circ} \mathrm{C}\right)$ can be converted to degrees Fahrenheit $\left({ }^{\circ} \mathrm{F}\right)$ by use of the following equation: ${ }^{\circ} \mathrm{F}=\left[1.8 \times{ }^{\circ} \mathrm{C}\right]+32$. 


\section{ACKNOWLEDGMENTS}

\section{Technical Reviewers}

Thomas J. Fogarty, Chief, Hydraulic and Environmental Engineering Branch, U.S. Army Corps of Engineers, Chicago, Ill.

Gary P. Johnson, Hydrologist, U.S. Geological Survey, Urbana, Ill.

Heather Henneman, Hydraulic Engineer, U.S. Army Corps of Engineers, Chicago, Ill.

Robert S. Bernard, Research Physicist, ERDC Waterways Experiment Station, U.S. Army Corps of Engineers, Vicksburg, Miss.

\section{Editorial and Graphics}

Terri L. Arnold, Cartographer, U.S. Geological Survey, Urbana, Ill.

Michael Eberle, Technical Publications Editor, U.S. Geological Survey, Columbus, Ohio

Michelle M. Greenwood, Cartographer, U.S. Geological Survey, Middleton, Wis.

Leah Hout, Editor, U.S. Geological Survey, Columbus, Ohio

Kathleen A. Hueschen, Student Trainee (Editor), U.S. Geological Survey, Middleton, Wis.

Susan Z. Jones, Editorial Assistant, U.S. Geological Survey, Middleton, Wis.

Aaron T. Konkol, Cartographer Aid, U.S. Geological Survey, Middleton, Wis.

\section{Approving Official}

Angel Martin, Jr., Acting Reports Improvement Advisor, U.S. Geological Survey, Urbana, Ill. 



\title{
One-Dimensional Simulation of Stratification and Dissolved Oxygen in McCook Reservoir, Illinois
}

\author{
By Dale M. Robertson
}

\section{Abstract}

As part of the Chicagoland Underflow Plan/Tunnel and Reservoir Plan, the U.S. Army Corps of Engineers, Chicago District, plans to build McCook Reservoir-a flood-control reservoir to store combined stormwater and raw sewage (combined sewage). To prevent the combined sewage in the reservoir from becoming anoxic and producing hydrogen sulfide gas, a coarse-bubble aeration system will be designed and installed on the basis of results from CUP 0-D, a zero-dimensional model, and MAC3D, a three-dimensional model. Two inherent assumptions in the application of MAC3D are that density stratification in the simulated water body is minimal or not present and that surface heat transfers are unimportant and, therefore, may be neglected. To test these assumptions, the previously tested, one-dimensional Dynamic Lake Model (DLM) was used to simulate changes in temperature and dissolved oxygen in the reservoir after a 1-in-100-year event. Results from model simulations indicate that the assumptions made in MAC3D application are valid as long as the aeration system, with an air-flow rate of 1.2 cubic meters per second or more, is operated while the combined sewage is stored in the reservoir. Results also indicate that the high biochemical oxygen demand of the combined sewage will quickly consume the dissolved oxygen stored in the reservoir and the dissolved oxygen transferred through the surface of the reservoir; therefore, oxygen must be supplied by either the rising bubbles of the aeration system (a process not incorporated in DLM) or some other technique to prevent anoxia.

\section{INTRODUCTION}

The Chicagoland Underflow Plan/Tunnel and Reservoir Plan is a flood-control plan for Chicago, Ill. As part of this plan, the U.S. Army Corps of Engineers (Corps), Chicago District, plans to design and build a flood-control reservoir-named McCook Reservoirto store excess combined stormwater and sewer overflows (combined sewage) (U.S. Army Corps of Engineers, 1999). During large storms, combined sewage will flow through a series of tunnels into this flood-control reservoir (fig. 1). The combined sewage may be stored up to six weeks until it can be treated at the Stickney Water Reclamation Plant. To counter anoxia and production of hydrogen sulfide gas because of the biochemical oxygen demand (BOD) of decomposing organic matter in the combined sewage, a coarse-bubble aeration system will be installed on the bottom of the reservoir and operated as soon as combined sewage enters the reservoir. The design and configuration of this system will be based on results from the Chicago Underflow Plan zero-dimensional model, CUP 0-D, developed by the Chicago District of the Corps (U.S. Army Corps of Engineers, 1999) and MAC3D, developed at the U.S. Army Engineer Waterways Experiment Station (WES) (Bernard, 1995). CUP 0-D is a zerodimensional model that can simulate several important biological, chemical, and physical processes, including aerobic decomposition that will occur in the tunnel system and various segments of the reservoir (U.S. Army Corps of Engineers, 1999). This model was used to estimate the amount of air needed to be used in the aeration system to maintain aerobic conditions in the reservoir (at least $2 \mathrm{mg} / \mathrm{L}$ ) for a 40 -year simulation period.

MAC3D is a three-dimensional, finite-volume, numerical model used to simulate buoyant incompressible flow; the model has been adapted to simulate the hydrodynamics in reservoirs induced by an aeration system (Bernard, 1997). MAC3D will be used to simulate the three-dimensional mixing in the reservoir and identify any potential unmixed zones (dead zones) between the diffusers of the aeration system.

The U.S. Geological Survey (USGS) measured the mixing dynamics in pilot-scale tests in a test tank at WES and in Egan Quarry, a small quarry near Schaumburg, Ill., (Johnson and others, 2000), and the results 


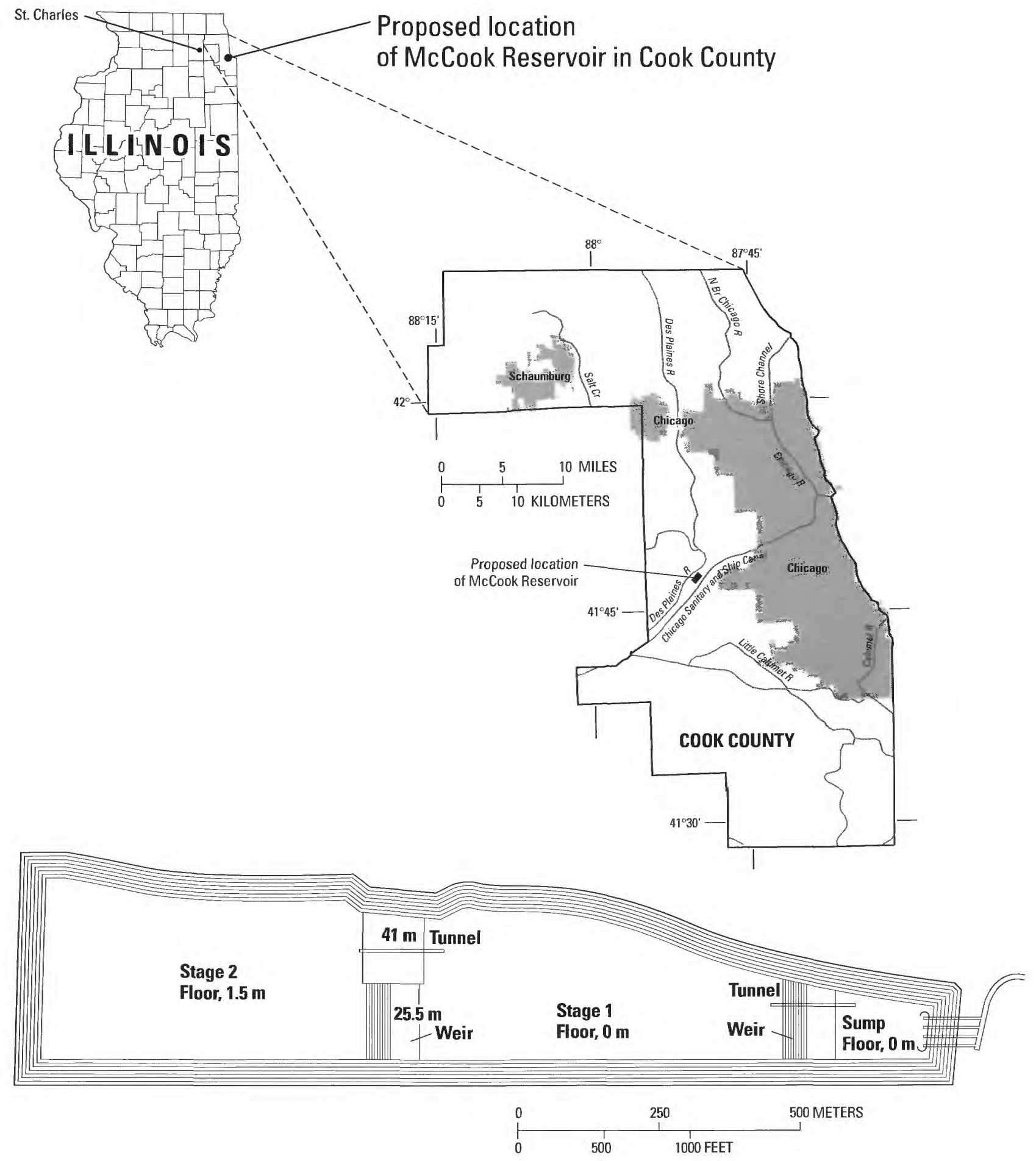

Figure 1. Schematic of McCook Reservoir, Ill., based on Chicagoland Underflow Plan. 
were compared with simulations by MAC3D (Bernard, 1998) to help evaluate the capabilities of MAC3D to simulate mixing dynamics in reservoirs, especially those that will result in McCook Reservoir associated with aeration. The mixing dynamics simulated by MAC3D were much different than those measured in Egan Quarry during stratified conditions. The discrepancies appear to be directly related to violations of two assumptions made within MAC3D: (1) density stratification in the water body is minimal or not present, and (2) surface heat transfers are unimportant and, therefore, may be neglected. In actuality, density stratification was not only present in Egan Quarry but also was a result of surface heat transfers. If aeration is used as soon as combined sewage is discharged into McCook Reservoir, however, heat transfers will probably be insufficient to cause stratification, and the assumption of little or no stratification should be valid. Therefore, MAC3D may still simulate the mixing dynamics adequately even if surface heat transfers are not incorporated into the model.

Mixing dynamics in the proposed McCook Reservoir with and without aeration were investigated by Price and Tillman (1991) using the one-dimensional, Corps of Engineers water-QUALity model for Reservoirs, CE-QUAL-R1, (Environmental Laboratory 1982), with an oxygen submodel added. The oxygen submodel simulates changes in oxygen and BOD by use of first-order reaction kinetics. In simulating the effects of aeration, it was assumed that oxygen was added to the reservoir through surface interactions only and not transferred from the rising bubbles of the aeration system to the ambient water. Results of this model indicated that, with sufficient aeration, the reservoir should remain destratified, but anoxia would develop almost immediately after filling and would persist while the reservoir was being emptied. An algorithm was added to this model to determine the amount of oxygen needed to be supplied to the reservoir to keep dissolved oxygen concentrations above 2 milligrams per liter $(\mathrm{mg} / \mathrm{L})$. Results from these simulations were then used to help design a preliminary oxygen-injection system. The oxygen-transfer efficiency of such a system was assumed to be a function of the height of the water column through which the oxygen bubbles rose (the oxygen-transfer efficiency, in percent, is approximately equal to twice the water column depth, in meters). Therefore, if the diffusers were placed at $46 \mathrm{~m}$ ( 150 feet) below the surface, approximately 90 percent of the oxygen in the bubbles should be transferred to the water. Results of this modeling study indicated that with sufficient aeration and with oxygen injection, the reservoir should remain destratified and aerobic.

The design of McCook Reservoir has changed since the original modeling study by Price and Tillman (1991). The new design is for a smaller but deeper reservoir: surface area of $395,000 \mathrm{~m}^{2}$ ( 98 acres) compared to the original area of $880,000 \mathrm{~m}^{2}(218$ acres $)$ and depth of approximately $77 \mathrm{~m}$ ( $250 \mathrm{feet})$ compared to the original depth of $48 \mathrm{~m}$ ( $150 \mathrm{feet})$. The capacity of the reservoir is also less than the original design $\left(27,000,000 \mathrm{~m}^{3}\right.$ compared to the original capacity of $39,500,000 \mathrm{~m}^{3}$ ). The design of the aeration system also has changed. The original system was designed only to maintain destratified conditions, and consisted of a single linear diffuser placed on the bottom of the reservoir, from which $1.2 \mathrm{~m}^{3} / \mathrm{s}$ of air (amount of air reaching the surface of the reservoir) would be released (Price and Tillman, 1991). The new system was designed to maintain destratified and aerobic conditions, and consists of 2,140 individual coarse-bubble diffusers placed throughout the reservoir in a rectangular grid design, from which $20.2 \mathrm{~m}^{3} / \mathrm{s}$ of air would be released. This amount of air supplied by the aeration system was based on results from CUP 0-D for a continuous 40-year historical period with over 800 storms (U.S. Army Corps of Engineers, 1999). CUP 0-D simulates air transfer through the surface of the reservoir and from the rising bubbles of the aeration system. CUP 0-D was developed and used because the original one-dimensional model did not incorporate oxygen transfer from the rising bubbles, and because the model was determined to be ineffective in estimating the oxygen demand exerted by the combined sewage because it could not simulate BOD's that vary throughout a storm and vary throughout the day in the reservoir. (The original model calculated oxygen demands on a daily basis.) The oxygen-transfer efficiency of the aeration system was assumed to vary with the depth of the reservoir, similar to that used in the oxygen-injection system of the previous one-dimensional modeling study; however, in this case, oxygen is transferred from rising air bubbles, which are composed of approximately 20 percent oxygen.

Because of the changes in the design of the reservoir and aeration system, the USGS, in cooperation with the Corps, conducted a study to reevaluate the possible interactions related to temperature and dissolved oxygen. In the study, the one-dimensional Dynamic Lake Model (DLM), previously shown to be capable of simulating changes in temperature and oxygen concen- 
trations in water bodies with surface heat transfers and a bubble-diffuser aeration system, was used to determine (1) how important surface heat transfers should be to the mixing processes in McCook Reservoir, (2) to what extent stratification should develop with and without aeration, and (3) whether anoxia will develop with and without aeration. The results of these model simulations are presented in this report.

\section{APPROACH}

To determine whether surface heat-transfer processes should be important and result in stratification in McCook Reservoir, DLM was used to simulate changes in the distribution of temperature and dissolved oxygen in the reservoir in response to a single designed event, a 1 -in-100-year inflow. During this event, more than $25,500,000 \mathrm{~m}^{3}(20,700$ acre- $\mathrm{ft})$ of combined sewage will drain into McCook Reservoir over a 2- to 3-day period and will keep the reservoir partly filled for about 28 days (H. Henneman, U.S. Army Corps of Engineers, Chicago District, written commun., 1999). This event was simulated for midsummer 1997. A midsummer simulation period was chosen because a major influx of combined sewage at this time should result in the worst water-quality conditions in the reservoir (strongest stratification and potentially lowest dissolved oxygen concentrations). The year 1997 (beginning on July 12, Julian day 193) was chosen because all of the meteorological data required by DLM were available from St. Charles, Ill., approximately $50 \mathrm{~km}$ west of Chicago.

The reservoir will be designed such that the water level in the reservoir during a 1-in-100-year event will be at least $10 \mathrm{~m}$ below the surrounding land surface. Hence, wind speed at the water surface may be much less than that measured approximately $3 \mathrm{~m}$ above the land surface at St. Charles. Therefore, simulations were done to determine the range in potential effects of the steep-sided, McCook Reservoir, using 100 percent (no effect of the steep sides of the reservoir) and 10 percent (maximum effect of the steep sides of the reservoir) of the wind measured at St. Charles. DLM was incapable of simulating changes in the reservoir if the wind was completely eliminated.

Four simulations were done to determine the extent of stratification and potential dissolved oxygen conditions with and without the new proposed aeration system and to determine possible effects of the steep-sided walls in the reservoir. An additional simulation was done to determine whether the air-flow rate of the ear- lier proposed aeration system (Price and Tillman, 1991) would maintain destratified conditions in the newsmaller but deeper-proposed reservoir. In each simulation, the reservoir was filled and emptied with the design inflow and outflow for the 1-in-100-year event.

Simulation 1-Full wind, no aeration: This simulation demonstrates base conditions in the reservoir if no aeration system is in place and weather conditions at the surface of the reservoir are similar to that just above the land surface at the nearby airport at St. Charles, Ill. This simulation is similar to one by Price and Tillman (1991), but with new reservoir dimensions.

Simulation 2-Full wind, full aeration: This simulation demonstrates the extent of stratification that should be present in McCook Reservoir if the new proposed aeration system (total air flow rate of $20.2 \mathrm{~m}^{3} / \mathrm{s}$ ) is used and the wind at the surface of the reservoir is similar to that just above the land surface at the nearby airport at St. Charles, Ill.

Simulation 3-Full wind, moderate aeration: This simulation demonstrates the extent of stratification that should be present in McCook Reservoir if a total airflow rate of $1.2 \mathrm{~m}^{3} / \mathrm{s}$ (air-flow rate in the original design) is used and the wind at the surface of the reservoir is similar to that just above the land surface at the nearby airport at St. Charles, Ill. This simulation is similar to one by Price and Tillman (1991), but with new reservoir dimensions.

Simulation 4-Reduced wind, no aeration: This simulation demonstrates the maximum potential effects of the steep-sided walls of the reservoir if no aeration system is in place. The daily wind data from St. Charles, Ill., are multiplied by 0.1 .

Simulation 5-Reduced wind, full aeration: This simulation demonstrates the maximum potential effects of the steep-sided walls of the reservoir if an aeration system, with a total air-flow rate of $20.2 \mathrm{~m}^{3} / \mathrm{s}$, is in place. The daily wind data from St. Charles, Ill., are multiplied by 0.1 .

\section{DYNAMIC LAKE MODEL}

DLM is a one-dimensional lake and reservoir model modified from the DYnamic REservoir Simulation Model, DYRESM (Imberger and Patterson, 1981) by McCord and others (2000). These models are process based and have been successfully used to simulate changes in the vertical temperature and oxygen structure of many lakes and reservoirs around the world. DLM is based on parameterizations of each specific 
mixing process, so site-specific model calibration is not necessary. This feature of DLM is especially important for examining mixing dynamics in reservoirs that have not yet been constructed. DLM is based on a

Lagrangian layer scheme in which the water body is represented by a series of horizontal layers, each with uniform properties but variable thickness. Surface heat transfers (short- and long-wave radiation, sensible heat transfer, and evaporation) are modeled by use of Beer's law for short-wave radiation and bulk aerodynamic formulae for the other processes. Mixed-layer deepening is simulated as convective overturn resulting from cooling and wind stirring at the surface and as seiche-induced shear and billowing resulting from shear instability at the pycnocline. Turbulent transport in the hypolimnion is simulated as a diffusion-like process, with an eddy diffusivity depending on the local density gradient and rate of dissipation of kinetic energy. Inflows and outflows generally are confined to narrow regions adjacent to the insertion and outflow levels of the water body (Patterson and Imberger, 1989).

Changes in dissolved oxygen are simulated as a function of mass transfers at the surface and reaction processes within the water body (McCord and others, 2000). A mass transfer of oxygen is computed for the area(s) at the surface near the rising plumes as a function of a reaeration constant and the gradient in oxygen concentrations between the rising water and the air (saturation). A mass transfer of oxygen also is computed for the area at the surface away from the rising plumes as a function of a different reaeration constant and the gradient in oxygen concentrations between the near-surface water and the air (saturation). Reaction processes include consumption of dissolved oxygen by BOD and vertical diffusion of dissolved oxygen between adjacent layers in the model. Consumption of dissolved oxygen by BOD represents respiration by organisms, decomposition of suspended organic matter, and oxidation of dissolved organic matter. Consumption of dissolved oxygen by BOD is simulated in the water column and at the sediment/water interface by use of different BOD rates.

A bubble-plume submodel was added to the models described above to simulate mixing induced by bubble-plume destratification systems (Schladow, 1992). In this submodel, each diffuser is treated as a point source of buoyancy, and the bubble plume is simulated by integrating the equations for mass, momentum, and buoyancy from the bottom of the water body to the surface. As a simulated plume rises through each computational layer, entrained water is added to the plume and the plume density is changed. At any height, if the widths of the rising plumes exceed the source spacing, the plumes can interact and be treated as a line source (Robertson and others, 1991). If the vertical velocity of the plumes decreases to zero, the water is detrained at that height and a new plume is restarted as a new source at the depth of the detrainments. The water detrained from the rising plumes then is inserted into the water column as a line source similar to tributary input. Therefore, the detrained water affects only the computational layers adjacent to the depth of the intrusion, but it will spread out vertically as a result of other mixing processes (Schladow, 1992).

In the present version of DLM, oxygen transfer is assumed to occur only at the surface of the reservoir, and no oxygen is transferred from the bubbles to the adjacent water. This assumption is similar to that made in the CE-QUAL-R1 model used by Price and Tillman (1991) in earlier simulations of McCook Reservoir.

\section{MODEL INPUTS}

Inputs to DLM include basin morphometry, meteorological data, inflow and outflow data, and initial water temperature and dissolved oxygen profiles. Daily averages of air temperature, vapor pressure, wind speed, and inflow characteristics (temperature, specific conductivity, dissolved oxygen concentration, and BOD) are used, whereas daily total values for inflows, outflows, long-wave radiation (or average percent of clear sky), short-wave radiation, and rainfall are used. To simulate the operation of an aeration system, the total air-flow rate (measured at the surface of the reservoir), number of diffusers, depth of diffusers, and diffuser spacing are required.

McCook Reservoir (fig. 1) will consist of three basins: a small sump area, Stage 1, and Stage 2 (U.S. Army Corps of Engineers, 1999). The basins will be separated by weirs that will extend about $25 \mathrm{~m}$ from the floor of the basin. The reservoir will have a total surface area of about $395,000 \mathrm{~m}^{2}$, a maximum length of about $1,700 \mathrm{~m}$, and a maximum width of about $425 \mathrm{~m}$. In modeling the reservoir, it was assumed that the weirs between basins did not affect stratification. The total 
area and volume of the reservoir as a function of depth are listed in table 1.

Table 1. Morphometry of McCook Reservoir, Ill. [Source: H. Henneman, U.S. Army Corps of Engineers, Chicago District, written commun., 1999; Abbreviations: m, meters; $\mathrm{m}^{2}$, square meters; $\mathrm{m}^{3}$, cubic meters. All values represent that for all three basins of the reservoir combined.]

\begin{tabular}{|c|c|c|}
\hline $\begin{array}{l}\text { Depth above Datum } \\
\text { (m) }\end{array}$ & $\begin{array}{c}\text { Area } \\
\left(\mathrm{m}^{2} \times 1000\right)\end{array}$ & $\begin{array}{c}\text { Volume } \\
\left(\mathrm{m}^{3} \times 1000\right)\end{array}$ \\
\hline 0.0 & 0.0 & 0.0 \\
\hline 1.2 & 140.3 & 171.2 \\
\hline 4.3 & 297.7 & $1,079.3$ \\
\hline 6.1 & 303.9 & $1,635.4$ \\
\hline 7.3 & 305.1 & $2,007.6$ \\
\hline 7.6 & 309.0 & $2,100.3$ \\
\hline 10.4 & 310.5 & $2,951.1$ \\
\hline 13.4 & 311.8 & $3,902.0$ \\
\hline 14.9 & 313.0 & $4,380.9$ \\
\hline 16.5 & 314.5 & $4,858.9$ \\
\hline 19.5 & 315.4 & $5,820.9$ \\
\hline 22.6 & 316.6 & $6,786.6$ \\
\hline 25.6 & 317.3 & $7,738.5$ \\
\hline 31.7 & 330.8 & $9,769.8$ \\
\hline 35.0 & 356.6 & $10,946.6$ \\
\hline 40.8 & 356.6 & $13,029.3$ \\
\hline 50.0 & 381.3 & $16,521.5$ \\
\hline 60.0 & 395.3 & $20,474.5$ \\
\hline 70.0 & 395.3 & $24,427.5$ \\
\hline 77.4 & 395.3 & $27,360.7$ \\
\hline
\end{tabular}

Meteorological data were obtained from St. Charles, Ill., approximately $50 \mathrm{~km}$ west of Chicago, from July to August 1997 and are illustrated in figure 2 for the dates during which the reservoir was simulated to contain combined sewage. (For a full description of the meteorological data, see Olson, 1998.) The precipitation data used in the simulations were those measured in 1997. The 1-in-100-year event affected only the inflow to the reservoir, not the precipitation to the surface of the reservoir.

During the 1-in-100-year event, it was estimated that more than $25,500,000 \mathrm{~m}^{3}$ of combined sewage will drain into McCook Reservoir over a 2- to 3-day period (H. Henneman, U.S. Army Corps of Engineers, Chicago District, written commun., 1999) and that two smaller storms will occur prior to treatment of all the combined sewage stored in the reservoir. In the model simulations, a volume of $16,500,000 \mathrm{~m}^{3}$ is added on day $193,5,000,000 \mathrm{~m}^{3}$ on day 194 , and $4,000,000 \mathrm{~m}^{3}$ on day 195 (fig. 3). The two smaller storms around days 203 and 210 result in small inflows on days 205 and 211 . The water quality of the inflows is assumed to be similar to that used in the earlier water-quality study for McCook Reservoir (Price and Tillman, 1991): water temperature of $20^{\circ} \mathrm{C}$, dissolved oxygen concentration of $6 \mathrm{mg} / \mathrm{L}$, and a 5 -day BOD of $30 \mathrm{mg} / \mathrm{L}$. These values are reasonable for inflows in July, but they would need to be modified if the timing of the design event is changed.

Immediately after the 1-in-100-year event, combined sewage stored in the deep tunnels will be treated before those stored in the reservoir. About 6 to 8 days will be required to treat the combined sewage stored in the tunnels; therefore, simulated outflow from the reservoir did not start until day 201. From day 201 onward, approximately $1,500,000$ to $2,000,000 \mathrm{~m}^{3}$ of combined sewage is treated per day; however, because of the two smaller storms around days 203 and 210 , there is no outflow from the reservoir on days 203-205 and 210. Outflow from the reservoir is simulated to continue until the water level reaches about $3 \mathrm{~m}$. The following day, the remaining combined sewage would be completely removed from the reservoir.

The present design of the aeration system to be installed in McCook Reservoir consists of 2,140 individual coarse-bubble diffusers (180 in the sump area, 790 in Stage 1, and 1,170 in Stage 2) placed just above the bottom of the reservoir (U.S. Army Corps of Engineers, 1999). The diffusers will be distributed in a rectangular grid design, with spacings of approximately $7.6 \mathrm{~m}$ by $15.2 \mathrm{~m}$. The total air-flow rate for this system is planned to be $20.2 \mathrm{~m}^{3} / \mathrm{s}$ (air flow measured at the water surface). The planned air-flow rate through each diffuser will depend on its location (from $0.016 \mathrm{~m}^{3} / \mathrm{s}$ in the sump area, to $0.011 \mathrm{~m}^{3} / \mathrm{s}$ in Stage 1 , to $0.008 \mathrm{~m}^{3} / \mathrm{s}$ in Stage 2). The average air-flow rate through all diffusers will be $0.009 \mathrm{~m}^{3} / \mathrm{s}$. In simulating the effects of the aeration system, each diffuser is assumed to be $1 \mathrm{~m}$ above the bottom, have an air-flow rate of $0.009 \mathrm{~m}^{3} / \mathrm{s}$, and be placed $7.6 \mathrm{~m}$ from adjacent diffusers.

In simulating the effects of the originally designed line-diffuser system, a total of $1.2 \mathrm{~m}^{3} / \mathrm{s}$ of air $\left(0.0002 \mathrm{~m}^{3} / \mathrm{s}\right.$ through each diffuser $)$ is released through 5,276 individual diffusers (the number of diffuser heads estimated to be needed to inject oxygen into the reservoir by Price and Tillman, 1991) placed $1 \mathrm{~m}$ apart and $1 \mathrm{~m}$ above the bottom of the reservoir. 

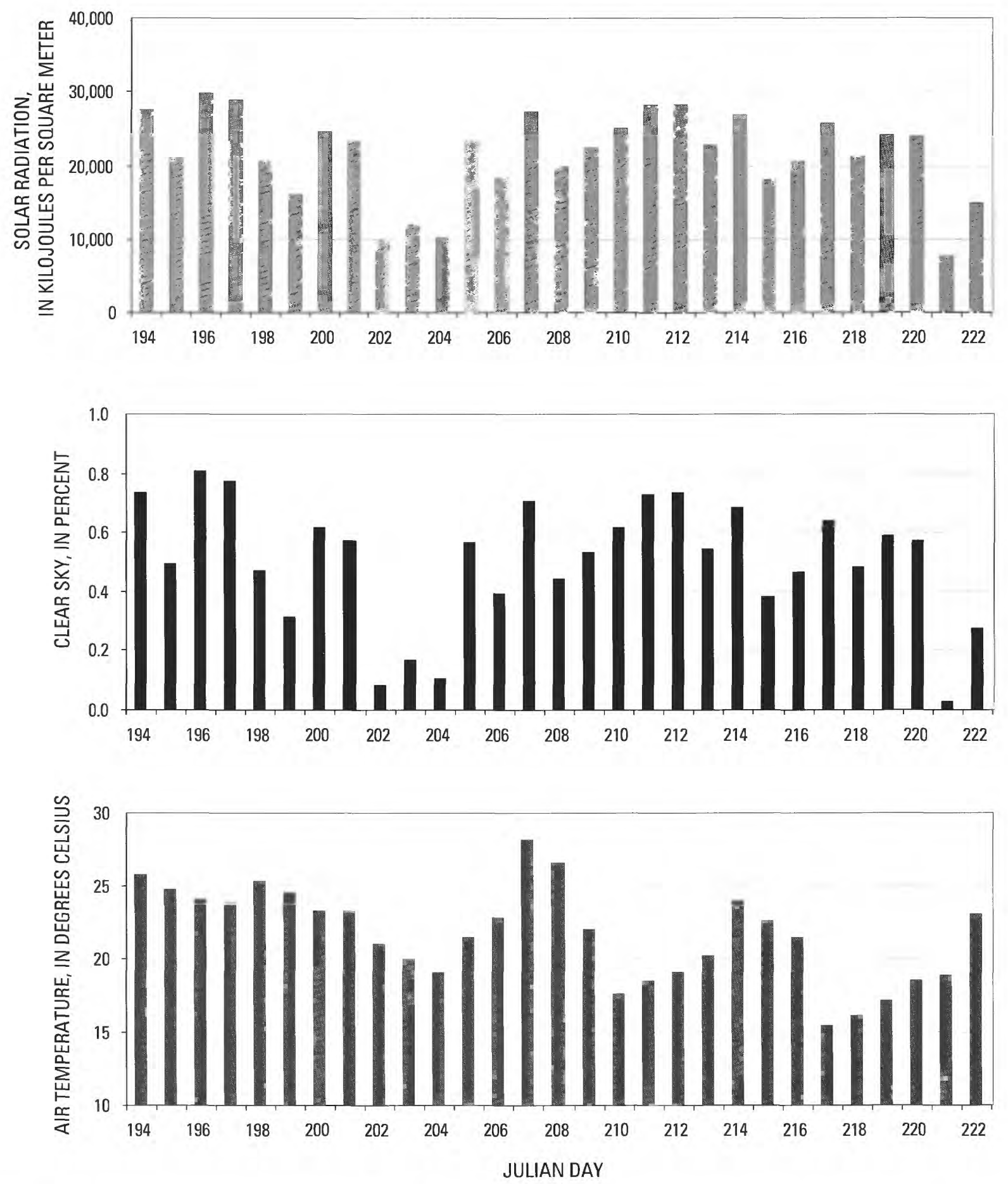

Figure 2. Daily average meteorological data from St. Charles, Ill, from July 13, 1997 (Julian day 194) to August 10, 1997 (Julian day 222). 

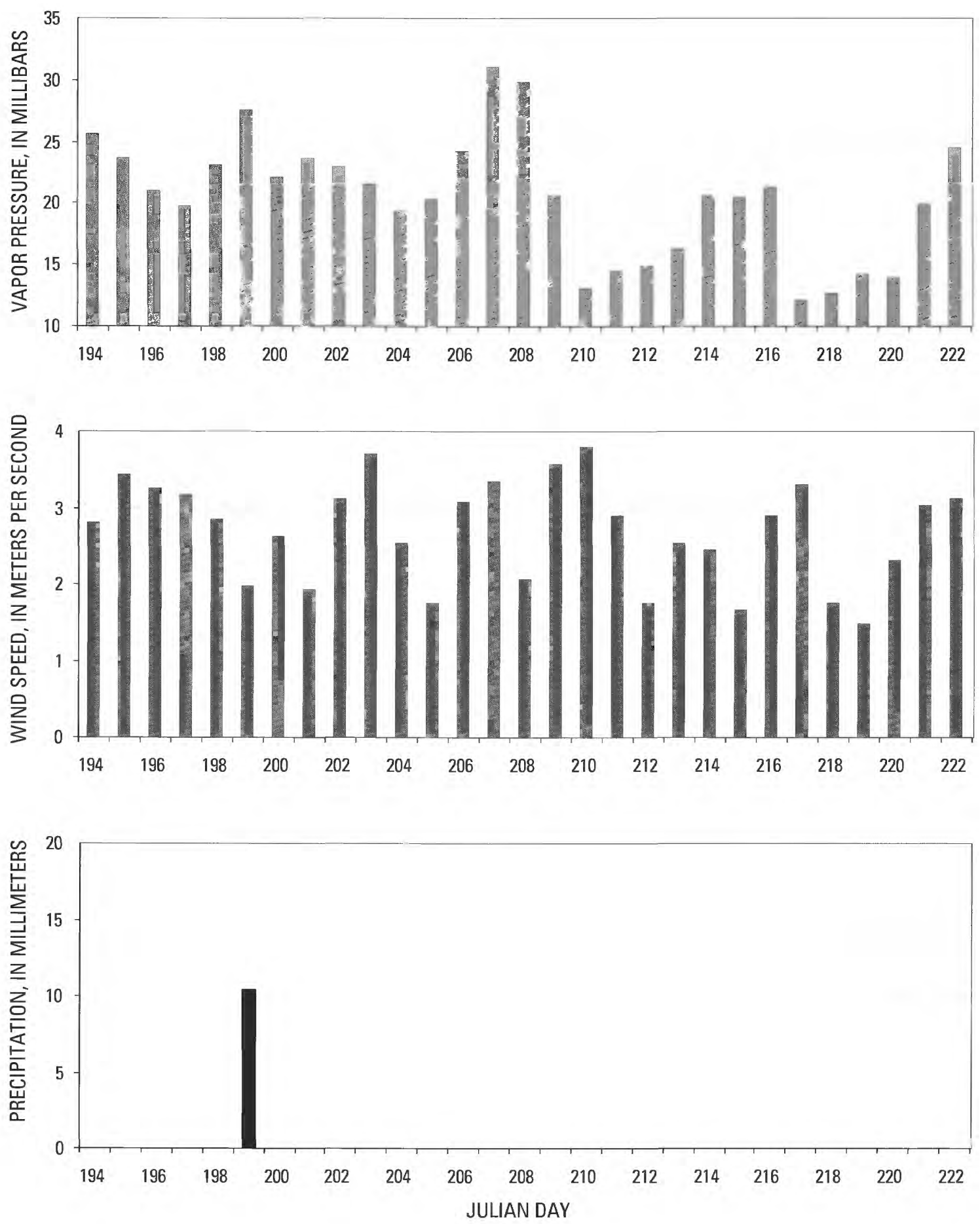

Figure 2. Daily average meterological data from St. Charles. Ill., from July 13, 1997 (Julian day 194) to August 10, 1997 (Julian day 222)Continued. 

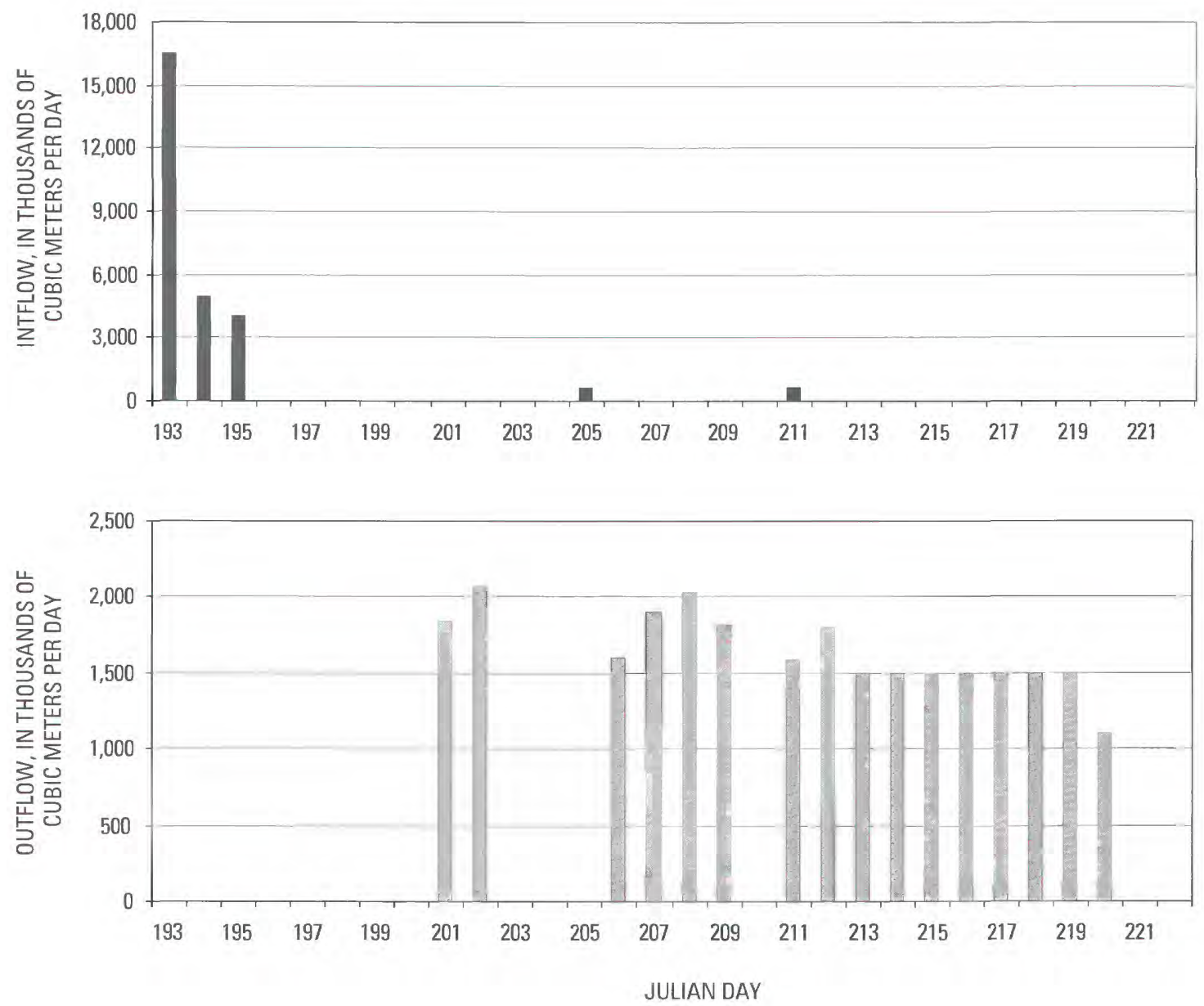

Figure 3. Total daily inflow to and outflow from McCook Reservoir. Ill., during the 1-in-100-year event beginning on July 12 (Julian day 193) (H. Henneman, Chicago District, U.S. Army Corps of Engineers, written commun., 1999).

\section{SIMULATION OF STRATIFICATION AND DISSOLVED OXYGEN}

The 1-in-100-year event on July 12 and 13 (Julian days 193 and 194) should cause the reservoir to fill to about $73 \mathrm{~m}$ in less than 3 days (figs. 4-8). The surface level will remain fairly stable for the following 6 days while combined sewage stored in the deep tunnels is treated by the Stickney Water Reclamation Plant. After the first 6 days, outflow from the reservoir will cause the water level to drop at a rate of about $5 \mathrm{~m}$ per day. Two smaller storms in the following days (around days 203 and 210) will cause temporary increases in water level. This series of storms will keep the reservoir partly filled for about 28 days.

\section{Simulation 1-Full Wind, No Aeration}

If the wind at the surface of the reservoir is unaffected by the steep-sided walls and aeration is not used, the reservoir should rapidly stratify and remain stratified throughout almost the entire period. Stratification in simulation 1 consists of a surface mixed layer with a depth of about 9 to $12 \mathrm{~m}$ and a bottom weakly stratified layer with temperatures about the same as the inflow temperature of $20^{\circ} \mathrm{C}$ (fig. 4a). Surface temperatures become especially warm around days 201,208, and 215 in association with warm air temperatures. Surface temperatures exceed $25^{\circ} \mathrm{C}$ on day 208. The warmer surface temperatures result in increased stratification during these periods. Stratification breaks down only near the 

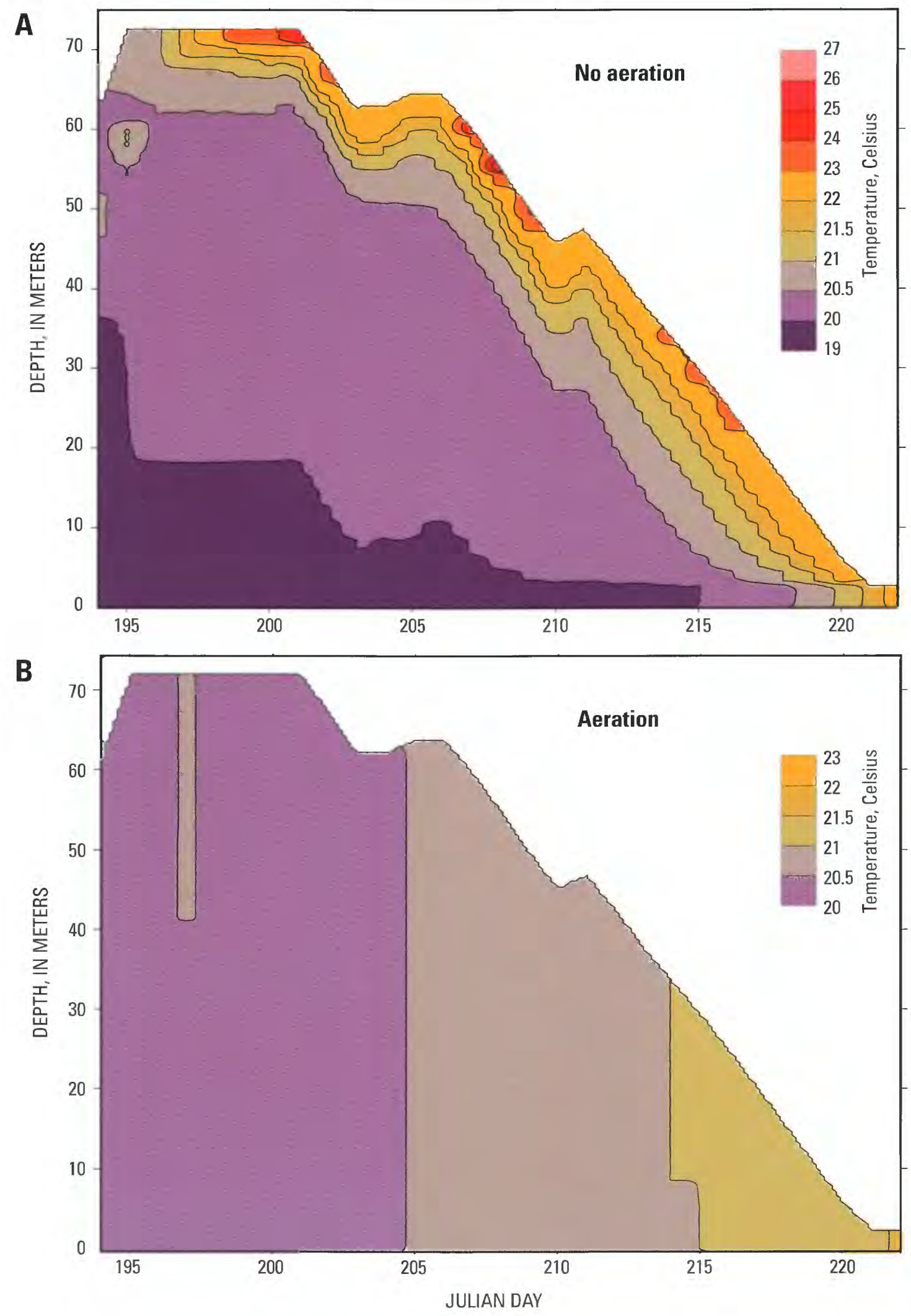

Figure 4. Water temperature distribution in McCook Reservoir. Ill., simulated by DLM following a 1-in-100-year event starting on July 12 (Julian day 193) using full wind speed at the surface of the quarry for (A) no aeration and (B) an aeration system operating with a total airflow rate of 20.2 cubic meters per second from 2.140 diffusers placed 7.6 meters apart. 
end of the simulation when the water level drops to about 4-5 m.

Although the combine sewage enters the reservoir with a dissolved oxygen concentration of $6 \mathrm{mg} / \mathrm{L}$, the dissolved oxygen in the reservoir is quickly consumed by the high BOD of the combined sewage. By day 195 (before the reservoir is completely filled), the reservoir becomes anoxic and remains nearly anoxic for the entire period that combined sewage is stored in the reservoir (fig. 5a). The small areas with oxygenated conditions around days 205 and 211 are associated with the inflow from the two small storms.

\section{Simulation 2-Full Wind, Full Aeration}

If the wind at the surface of the reservoir is unaffected by the steep-sided walls but aeration (total airflow rate of $20.2 \mathrm{~m}^{3} / \mathrm{s}$ released from 2,140 diffusers placed $7.6 \mathrm{~m}$ apart) is used, the reservoir should remain virtually unstratified throughout the entire period. The temperature of the reservoir in simulation 2 slowly but uniformly increases from about $20^{\circ} \mathrm{C}$ on day 194 to about $21.5^{\circ} \mathrm{C}$ by day 222 (fig. 4b). No surface layer forms even during the warmest days.

Even with aeration, results from DLM indicate the reservoir should quickly go anoxic and remain anoxic until about day 219 , when about $12 \mathrm{~m}$ of combined sewage is in the reservoir (fig. 5b). The brief presence of dissolved oxygen near the surface on day 194 is not seen when aeration is used. After day 219, dissolved oxygen concentrations quickly increase from near $0 \mathrm{mg} / \mathrm{L}$ to about $8 \mathrm{mg} / \mathrm{L}$ by day 222 .

\section{Simulation 3-Full Wind, Moderate Aeration}

If the wind at the surface of the reservoir is unaffected by the steep-sided walls but the original aeration design (total air-flow rate of $1.2 \mathrm{~m}^{3} / \mathrm{s}$ released though about 5,000 diffusers) is used, the reservoir still should remain virtually unstratified throughout the entire period. The temperature of the reservoir in simulation 3 slowly but uniformly increases from about $20^{\circ} \mathrm{C}$ on day 194 to about $21.5^{\circ} \mathrm{C}$ by day 222 (fig. $6 a$ ). With moderate aeration, the reservoir should quickly go anoxic and remain anoxic until about day 217 (fig. 6b), when about $15 \mathrm{~m}$ of combined sewage is in the reservoir. These results are similar to those found when a higher air-flow rate is simulated (fig. 5 b).

\section{Simulation 4-Reduced Wind, No Aeration}

If the wind at the surface of the reservoir is strongly affected by the steep-sided walls (simulated to be only 10 percent of the wind measured just above the surface of the quarry) and aeration is not used, the reservoir should rapidly stratify and remain stratified throughout the entire period it contains combined sewage. Stratification in simulation 4 consists of a mixed surface layer with a depth of about 7 to $11 \mathrm{~m}$ and a weakly stratified bottom layer with temperatures similar to the inflow temperature of $20^{\circ} \mathrm{C}$ (fig. 7a). With the wind speeds reduced by 90 percent, the surface layer is slightly shallower (by about $1 \mathrm{~m}$ ) and warmer (by about 3 to $4^{\circ} \mathrm{C}$ ) than in simulation 1 (full wind). Surface temperatures frequently exceed $27^{\circ} \mathrm{C}$ and occasionally reach almost $29^{\circ} \mathrm{C}$, but they cool to about $25-26^{\circ} \mathrm{C}$ on other days. With a shallower and warmer mixed layer than in simulation 1 (full wind), stratification is much stronger than if the surface of the reservoir is affected by the full strength of the wind.

The dissolved oxygen in the reservoir is quickly consumed by the high BOD of the combined sewage (fig. 8a). The short-term presence of dissolved oxygen near the surface observed in simulation 1 persists about 2 days with the reduced wind speeds in simulation 4 . By day 195 (about the time the reservoir completely fills), the reservoir becomes anoxic and remains nearly anoxic for the entire period.

\section{Simulation 5-Reduced Wind, Full Aeration}

If the wind at the surface of the reservoir is strongly affected by the steep-sided walls and aeration (total airflow rate of $20.2 \mathrm{~m}^{3} / \mathrm{s}$ released from 2,140 diffusers placed $7.6 \mathrm{~m}$ apart) is used, the reservoir should remain virtually unstratified throughout the entire period. The temperature of the reservoir in simulation 5 slowly but uniformly increases to about $22^{\circ} \mathrm{C}$ (fig. $7 \mathrm{~b}$ ). No surface layer forms even during the warmest days. Similar results are found when the original aeration design (total air-flow rate of $1.2 \mathrm{~m}^{3} / \mathrm{s}$ ) in simulation 3 is simulated with reduced wind speeds.

Even with aeration, results from DLM again indicate the reservoir should go anoxic in 12 to 24 hours and remain anoxic until about day 219 when the water level is about $12 \mathrm{~m}$ (fig. 8b). The short-term presence of dissolved oxygen near the surface while the reservoir is filling does not occur when aeration is used. After day 

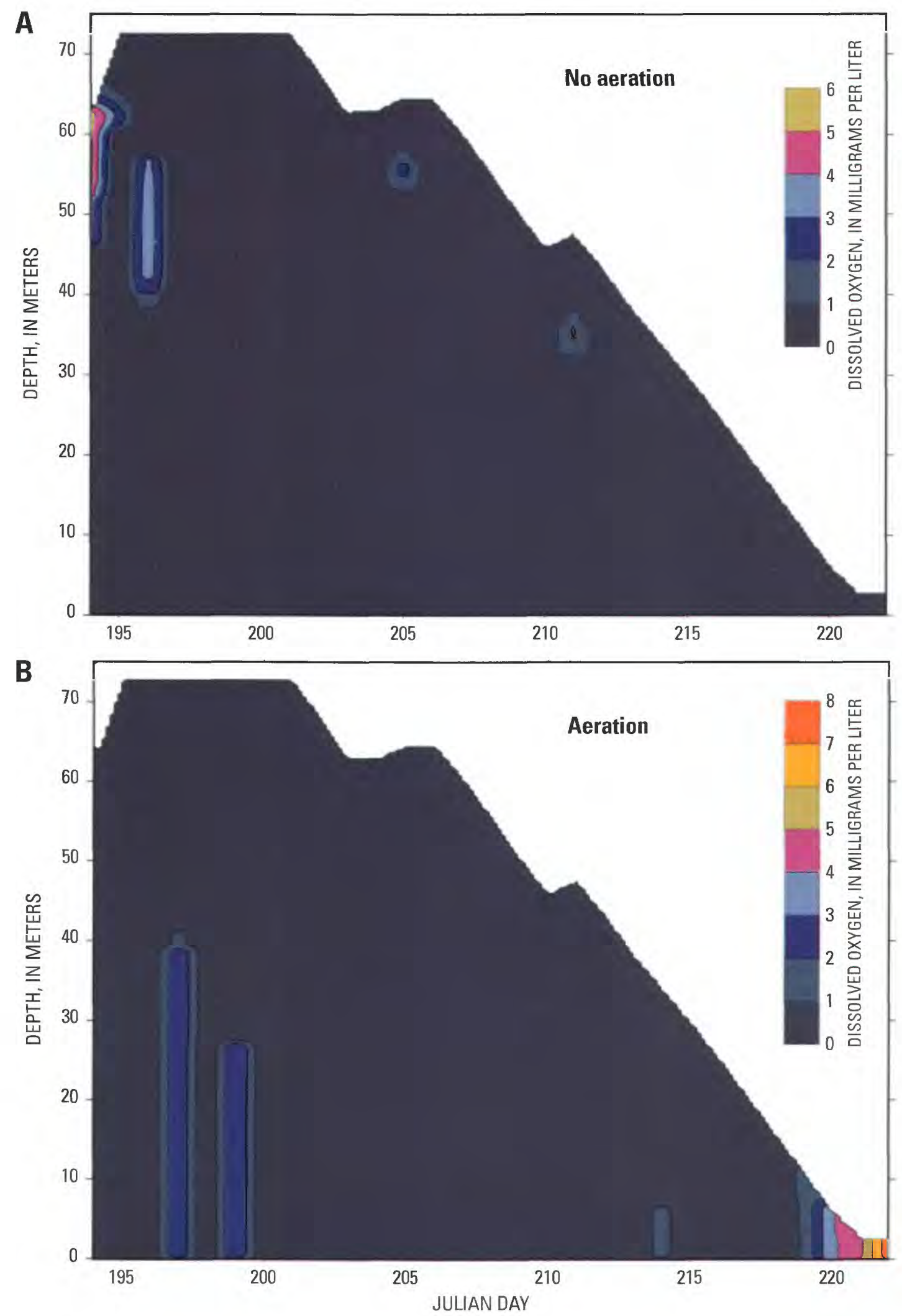

Figure 5. Dissolved oxygen distribution in McCook Reservoir, Ill., simulated by DLM following a 1-in-100-year event starting on July 12 (Julian day 193) using the full wind speed at the surface of the quarry for (A) no aeration and (B) an aeration system operating with a total airflow rate of 20.2 cubic meters per seconds from 2,140 diffusers placed 7.6 meters apart. 

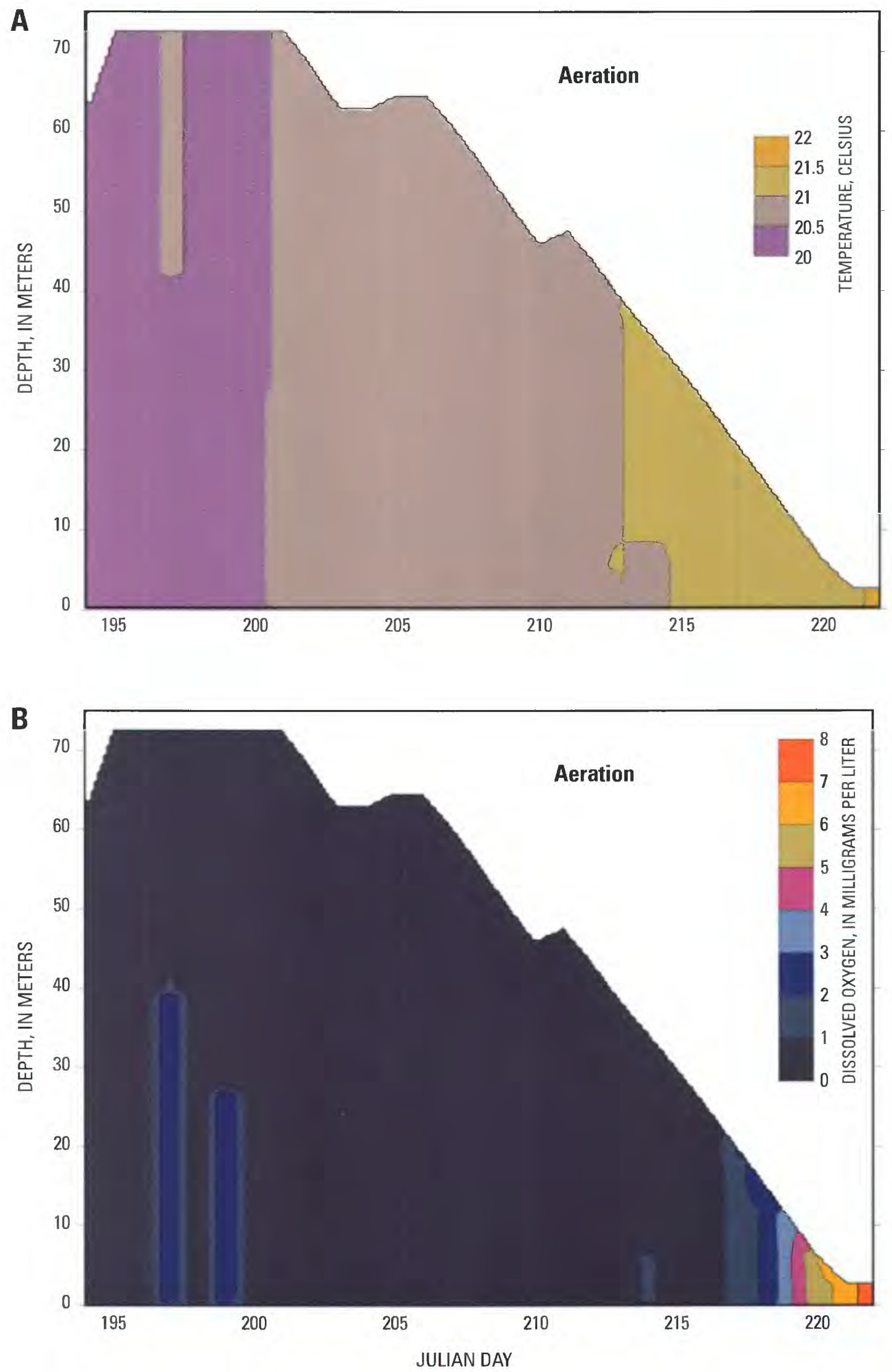

Figure 6. (A) Temperature and (B) dissolved oxygen distributions in McCook Reservoir, Ill., simulated by DLM following a 1-in100-year event starting on July 12 (Julian day 193) using full wind speed at the surface of the quarry for an aeration system operating with a total air-flow rate of 1.2 cubic meters per second from 5,276 diffusers placed 1 meter apart. 

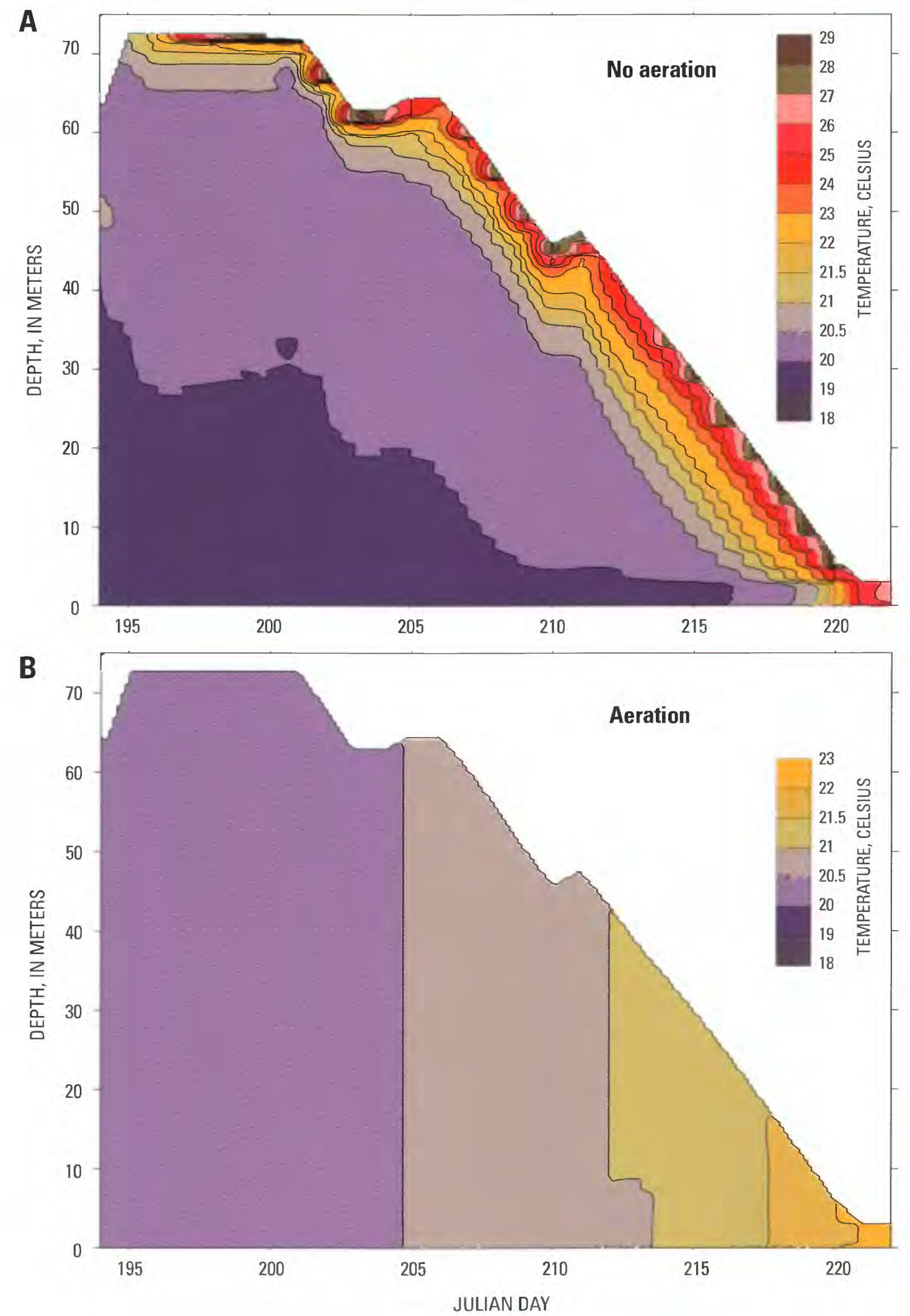

Figure 7. Water temperature distribution in McCook Reservoir, Ill., simulated by DLM following a 1-in-100-year event starting on July 12 (Julian day 193) for reduced wind speeds ( 10 percent of that at the surface of the quarry) for (A) no aeration and (B) an aeration system operating with a total airflow rate of 20.2 cubic meters per second from 2,140 diffusers placed 7.6 meters apart. 

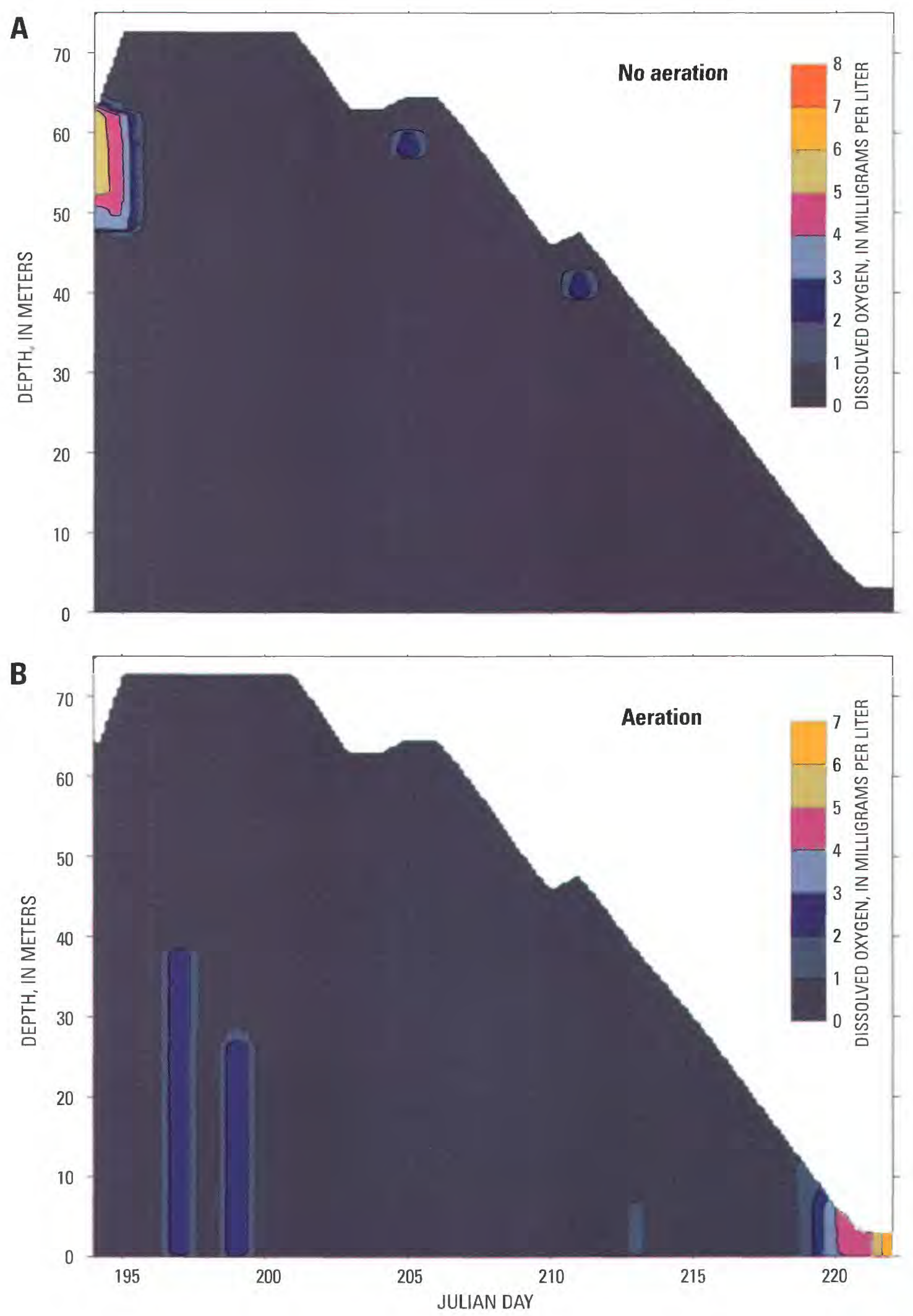

Figure 8. Dissolved oxygen distribution in McCook Reservoir, Ill., simulated by DLM following a 1-in-100-year event starting on July 12 (Julian day 193) for reduced wind speeds (10 percent of that at the surface of the quarry) for (A) no aeration and (B) an aeration system operating with local airflow rate of 20.2 cubic meters per second from 2,140 diffusers place 7.6 meters apart. 
219 , dissolved oxygen concentrations quickly increase from near $0 \mathrm{mg} / \mathrm{L}$ to about $7 \mathrm{mg} / \mathrm{L}$ by day 222 .

\section{EFFECTS WIND AND AERATION HAVE ON STRATIFICATION AND DISSOLVED OXYGEN}

Stratification should develop very quickly in McCook Reservoir after a summer storm if aeration is not used. The stratification then should persist until the water level drops below about $4 \mathrm{~m}$ regardless of to what extent the wind speed is affected by the steep-sided walls of the reservoir, although stratification will be stronger if wind speed at the surface of the reservoir is decreased from that just above the top of the quarry. The intensity of the stratification in the reservoir will depend on when the event occurs seasonally. Strongest stratification should develop when inflow temperatures are much lower than the ambient air temperatures and when solar radiation is intense, such as observed in these midsummer simulations. If the storm occurs between October and March, stratification should not develop.

Without aeration, dissolved oxygen throughout the reservoir should quickly be depleted, and the reservoir should remain anoxic for almost the entire period when combined sewage is in the reservoir.

With a total air-flow rate of $20.2 \mathrm{~m}^{3} / \mathrm{s}$ released through over 2,000 diffusers, the reservoir should remain unstratified regardless of the effect the steepsided reservoir has on wind speeds. The reservoir may gradually but uniformly warm or cool depending on the season during which the inflow event occurs. Therefore, if aeration is used, surface heat transfers to McCook Reservoir should be relatively unimportant as to whether stratification does or does not occur.

The total air-flow rate used in these simulations was about 17 times more than used by Price and Tillman (1991); however, the simulation results were virtually the same. Both modeling studies demonstrated that, with aeration, the reservoir would remain unstratified, but anoxia would develop quickly and persist during most of the remaining period. This study also demonstrated that even with the deeper, newer design of the reservoir, $1.2 \mathrm{~m}^{3} / \mathrm{s}$ (the total air-flow rate used in the original design of the aeration system) would be adequate to maintain destratified conditions in the reservoir.

Even with aeration, results from DLM indicate that the reservoir should go anoxic within 12 to 24 hours and remain anoxic until the water level drops to about $12 \mathrm{~m}$.
In computing changes in dissolved oxygen concentrations in the reservoir, however, DLM accounts for oxygen transfer to the reservoir only at the surface or with inflow. Therefore, the model indicates the high BOD of the combined sewage would consume more oxygen than is present in the reservoir or can be transferred through the surface of the reservoir until after about 24 days. The assumption of no oxygen transfer from the rising bubbles is similar to that made in the earlier model simulations for McCook Reservoir (Price and Tillman, 1991) and produced results similar to those of the earlier study. In reality, some of the oxygen in the air bubbles will diffuse into the water column as the bubbles rise. Price and Tillman (1991) present a graph of oxygen-transfer efficiency as a function of the height of rise of oxygen bubbles. This graph indicates that the oxygen transfer should be 100-percent efficient if oxygen bubbles rise over about $50 \mathrm{~m}$. This relation, however, was based on studies using various bubble sizes and types of diffusers and was primarily based on studies with pure oxygen bubbles, not ambient-air bubbles. Therefore, oxygen transfer from air bubbles may be less efficient than that presented in this graph (Price and Tillman, 1991). A more detailed examination of oxygen-transfer efficiencies from ambient-air bubbles would be useful in validation of existing dynamic models prior their use in the design of an aeration system for McCook Reservoir.

\section{CONCLUSIONS}

In response to a 1-in-100-year event occurring during summer, McCook Reservoir will fill with approximately $73 \mathrm{~m}$ of combined sewage. To treat the combined sewage and drain the reservoir will take approximately 28 days. Results from the one-dimensional DLM indicate that during this time, strong stratification will result in the reservoir unless an aeration/ destratification device is used. Results also indicate that a total air-flow rate of either $1.2 \mathrm{~m}^{3} / \mathrm{s}$ (original aerationsystem design) or $20.2 \mathrm{~m}^{3} / \mathrm{s}$ (present aeration-system design) will maintain destratified conditions in the reservoir regardless of when during the year this event occurs and that the high BOD of the combined sewage will quickly consume the oxygen in the reservoir and more oxygen than can be transferred through the surface of the reservoir. Therefore, to prevent anoxia, oxygen must be supplied by either rising bubbles of an aeration system or some other technique. 
The Corps plans to use MAC3D to help design an aeration system for McCook Reservoir. If an aeration system, such as those examined here, is used in McCook Reservoir, surface heat transfers should be inconsequential and stratification should not develop. Therefore, the assumption of little or no stratification used in MAC3D should be valid, and the model may simulate the mixing dynamics satisfactorily even if surface heat transfers are not incorporated into the model. Further development of a one-dimensional model that incorporates oxygen transfer from rising bubbles of an aeration system would be useful to help validate oxygen algorithms in MAC3D and determine the relative importance of oxygen transfer at the surface compared to the oxygen transfer from air bubbles of an aeration system.

\section{REFERENCES}

Bernard, R.S., 1995, Preliminary development of a threedimensional numerical model for reservoir hydrodynamics: U.S. Army Engineer Waterways Experiment Station, Vicksburg, Miss., Technical Report HL-95-9, $92 \mathrm{p}$.

Bernard, R.S., 1997, Extension and validation of the MAC3D numerical model for applications involving bubble diffusers, in Proceedings of the 27th Congress of the International Association for Hydraulic Research, San Francisco, Calif., August 10-15, 1997, Theme B.

Bernard, R.S., 1998, MAC3D: Numerical model for reservoir hydrodynamics with application to bubble diffusers: U.S. Army Engineer Waterways Experiment Station, Vicksburg, Miss., Technical Report CHL-98-23, 112 p.

Environmental Laboratory, 1982, CE-Qual-R1: A numerical one-dimensional model of reservoir water quality; User's manual: U.S. Army Engineer Waterways Experiment Station, Vicksburg, Miss., Instruction Report E 82-1,

Johnson, G.P., Hornewer, N.J., Robertson, D.M., and Olson, D.T., 2000, Methodology, data collection, and data analysis for determination of water-mixing patterns resulting from operation of aerators and mixers: U.S. Geological
Survey Water-Resources Investigations Report 00-4101, $72 \mathrm{p}$.

Imberger, J., and Patterson, J.C., 1981, A dynamic reservoir simulation model, DYRESM 5. In Fischer, H.B., ed., Transport models for inland and coastal waters, New York, Academic Press, p. 301-361.

McCord, S.A., Schladow, S.G., and Miller, T.G., 2000, Modeling artificial aeration kinetics in ice covered lakes: Journal of Environmental Engineering, v. 26, no. 1, p. 21-31.

Olson, D.T., 1998, The thermal response of a small water body to bubble-plume destratification: Dept. of Civil Engineering, University of Illinois at Urbana-Champaign, M.S. thesis, $162 \mathrm{p}$.

Patterson, J.C., and Imberger, J., 1989, Simulation of bubble plume destratification in reservoirs: Aquatic Science, v. 51 , no. 1 , p. $3-18$.

Price, R.E., and Tillman, D., 1991, McCook Reservoir water quality model: Numerical model investigation: U.S. Army Engineer Waterways Experiment Station, Vicksburg, Miss., Technical Report HL-91-17, p 51.

Robertson, D.M., Schladow, S.G., and Patterson, J.C., 1991, Interacting bubble plumes: The effect on aerator design, in Lee, J.H.W. and Cheung, Y.K., eds., Environmental hydraulics, Proceedings of the International Symposium on Environmental Hydraulics, Hong Kong: Rotterdam, A.A. Balkema, p. 173-179.

Schladow, S.G., 1992, Bubble plume dynamics in a stratified medium and the implications for water quality amelioration in lakes: Water Resources Research, v. 28, no. 2, p. 313-321.

U.S. Army Corps of Engineers, 1999, Chicagoland underflow plan McCook Reservoir, Illinois, design documentation report, volume 7, appendix $\mathrm{H}-$ Aeration and washdown: Chicago District, Hydraulic and Environmental Engineering Branch, 238 p. plus attachments. 
8 Printed on recycled paper 

